\title{
Is Agricultural Credit Programme Effective in Boro Cultivation? Evidence from State-owned Bank of Mymensingh District
}

\author{
L Deb $^{1 *}$, M A R Sarkar ${ }^{1}$, M A B Siddique ${ }^{1}$ and R Begum ${ }^{2}$
}

\begin{abstract}
High input-intensive Boro rice cultivation needs substantial agricultural credit for the resource-poor Bangladeshi farmers. An investigation was conducted at Fulbaria upazila of Mymensingh district to assess loan attainment cost from Bangladesh Krishi Bank (BKB) and its utilization pattern; evaluate the effects of credit on Boro cultivation, and identify the major drivers of the agricultural credit programme. For the study, 140 farmers were divided into two groups: those who took a loan from $\mathrm{BKB}$ and those who did not. Results revealed that the borrowers had to pay Tk 10.23 for getting a hundred taka loan from BKB most of which was an unofficial cost. More than half of the obtained loan was used for Boro cultivation whereas $21 \%$ was used for family consumption and the rest (25\%) was used for other purposes such as reimbursement of the previous loan from formal and informal sources, wedding and other income-generating activities including petty business. BKB credit borrowers obtained more benefits through Boro cultivation than non-borrowers. The major strengths of the BKB's agricultural credit programme were well-established infrastructure, experienced manpower, country-wide network, and lower interest rate. Whereas complex and lengthy institutional procedures, the inevitability of collateral and poor institutional capacity were being revealed as the weaknesses of the programme. Prevalence of brokers or corrupt officials and political influence were identified as the major constraints for the loan acquirement. More advanced research is recommended, with an emphasis on agricultural credit programmes, to ensure their effectiveness.
\end{abstract}

Key words: Bangladesh Krishi Bank, cost of credit, credit utilization, profitability, drivers of credit.

\section{INTRODUCTION}

Agriculture is still considered as the driving force of the rural economy of Bangladesh, which is heading towards commercialization to cope up with increased demand and rapid industrialization (Deb, 2016). It is well documented that the recent technological breakthrough that was incepted by Green Revolution has not only resulted in increased productivity but also brought significant changes in the magnitude and structure of cost associated with production process (Alauddin and Biswas, 2014a). Poor farmers in developing countries are often incompetent to afford the cost of crop production from their own sources which resulting in the delayed application of inputs even forcing them to apply less or lower quality inputs sometimes (Binswanger-Mkhize, 2012). Few farm expenses need to be paid within the shortest time even before the harvesting of crops and short-term credit become a foreseeable necessity (Khan et al., 2017). Furthermore, Alauddin and Biswas, 2014a noticed that even though rich and middle-class farmers who are assumed to be in a good position in terms of solvency, also feel the inevitability of credit in a certain period, particularly during Boro season in Bangladesh. As a result, farmers' crop production is reliant on rural financial markets. The Bangladeshi rural financial market is divided into three categories: formal sector, semi-formal sector, and informal sector. State-owned specialized and commercial banks, along with private commercial banks, make up the formal market. In Bangladesh, state-owned banks both specialized and commercial are still

\footnotetext{
${ }^{1}$ Agricultural Economics Division, Bangladesh Rice Research Institute, Gazipur 1701, Bangladesh

${ }^{2}$ Department of Agricultural Finance and Cooperatives, Bangabandhu Sheikh Mujibur Rahman Agricultural University, Salna, Gazipur, Bangladesh

${ }^{*}$ Corresponding author's E-mail: limondeb.bau@gmail.com
} 
recognized as the main sources of agricultural financing (Alauddin and Biswas, 2014b). Among the specialized banks, BKB, Rajshahi Krishi Unnayan Bank (RAKUB) and other state-owned commercial banks (SCBs) are the dominant players in the expanse of agricultural credit in the country, more specifically in the rural farming community (BB, 2018). At the same time despite the higher rate of interest, a large number of farmers borrow money from informal sources (e.g., friends, relatives, commission agents, traders, private money-lenders, and mohazons) to avoid the lengthy bureaucratic process and rigid reimbursement system of most formal sources. But it was observed that outflows as the interest charges on such informal loans result in a major drain in the income of the small even medium and large farmers, which dampen their living standard and make them perpetually indebted (Deb et al., 2016). Farmers in Bangladesh are well aware of this scenario nowadays (Alauddin and Biswas, 2014a). To escape from the hassle that exists in the formal credit sources and to avoid the vicious cycle of indebtedness of informal sources (Salam et al., 2019), farmers often rely on their own sources of funding, which is inadequate mostly in the case of small or medium farmers. As a result, non-borrower farmers often fall behind in terms of productivity or profitability, as productivity varies between borrowers and non-borrowers, with borrowers being in a stronger position to accelerate the adoption of modern technologies (inputs and machinery) (Spio, 2006). Again, a timely flow of agricultural credit, which fulfills farmers' demand, is a prerequisite for ensuring higher agricultural productivity (Alauddin and Biswas, 2014b).

The Bangladesh Krishi Bank was established under the Bangladesh Krishi Bank Order 1973 to promote the agricultural development of Bangladesh. From the very beginning, the main and foremost focus of $\mathrm{BKB}$ is to make institutional credit accessible to the rural community. It has established several branches in the distant rural parts of the country, often in areas with a weak economic base. As mentioned before the main sources of agricultural credit here are still state-owned banks among which BKB is the most dominant one (Alauddin and Biswas, 2014a). In Fiscal Year (FY) 2016-17, 28 percent of the total disbursement of agricultural credit was made by BKB solely. Table 1 presents the contribution of BKB in agricultural lending in 2016-17.

Table 1. Agricultural credit performance by lenders in the fiscal year 2016-17.

\begin{tabular}{cccc}
\hline Lender & Number of entities & $\begin{array}{c}\text { Disbursement Target } \\
\text { (Billion Taka) }\end{array}$ & $\begin{array}{c}\text { Actual Disbursement } \\
\text { (Billion Taka) }\end{array}$ \\
\hline SCBs & 6 & 28.90 & 27.21 \\
BKB & 1 & 48.00 & 49.40 \\
RAKUB & 1 & 16.00 & 11.15 \\
Sub Total & 8 & 92.90 & 87.86 \\
FCBs & 9 & 3.93 & 5.10 \\
PCBs & 38 & 67.17 & 83.60 \\
Sub Total & 47 & 71.10 & 88.70 \\
Grand Total & 55 & 164.00 & 176.46 \\
\hline
\end{tabular}

Note: SCBs: State-owned Commercial Banks; BKB: Bangladesh Krishi Bank; RAKUB: Rajshahi Krishi Unnyan Bank; FCBs: Foreign Commercial Banks; PCBs: Private Commercial Banks.

Source: Agricultural Credit Department, Bangladesh Bank. 
Attainment of the agricultural credit programme typically relies on the borrowers' side as well. A few studies have been made so far addressing the insight of the agricultural credit programme from the borrowers' perspective. The concept of this research has been made purposively. There are various sources of agricultural credit for lending. Among these sources, the state-owned source is the bank, from where loans are available at a lower interest rate. However, due to various bureaucratic complications, farmers have to face many difficulties in getting loans. BKB, as one of the important state-owned sources, has agricultural credit programme. Therefore, this study is intended to look at the effectiveness of $B K B$ 's agricultural credit programme. BKB provides various crop-based agricultural loans. In this study, we have purposively selected the Boro rice crop as it plays a significant role in the food security of Bangladesh. Farmers, on the other hand, use more production inputs during Boro season. This increases the production costs of farmers (Rahman and AlAmin, 2016). At that time the farmers become financially indigent and dependent on loans. So the real picture of the agricultural credit programme would be better portrayed at this time. Hence, we have undertaken a study on the effect of the agricultural credit programme on Boro rice cultivation.

Boro rice farmers in the Mymensingh district take a loan from BKB as one of the lending sources of low-interest rates. It is so often presumed that the credit taken for agricultural purposes more precisely for Boro rice cultivation is not merely used for the purpose. Therefore, when the loan is advanced to the farmers, they use it according to their priority of needs. On the other hand, there are some unwanted costs involved in obtaining agricultural credit (Miah et al., 2006). Therefore, it is needed to know how much is the cost for the borrowers to obtain the credit, how it is being used, and what is the impact of those credits in Boro cultivation. Thus, the study has focused to assess the cost of getting a loan and its utilization pattern; to evaluate the effects of credit on the profitability of Boro cultivation by borrowers and non-borrowers, and identify the major drivers of BKB's agricultural credit programme in the study areas.

\section{MATERIALS AND METHODS}

The study was conducted in Fulbaria upazila of Mymensingh District purposively. Two criteria were set for respondent selection; (i) who only took loans in the fiscal year 2016-17, and (ii) who only took loans for Boro rice cultivation. Based on these criteria, we have collected the list of borrowers from BKB's Fulbaria branch, where 70 respondents (farmers) were selected randomly from the listed 90 borrowers (credit users) of the branch and the other 70 farmers (credit non-users) were also selected randomly from the Department of Agricultural Extension (DAE) listed Boro farmers of the same village. Therefore, the total sample size of the study was 140. Both the credit users and non-user were interviewed using a pre-designed semistructured questionnaire during June 2017. Descriptive statistics mainly in tabular form were used to analyze and interpret the surveyed data. In this study, financial (cost and return) analyses were done on both variable or cash and full cost basis.

The profitability of Boro rice was estimated by applying the conventional profit equation as follows:

$\Pi=\mathrm{TR}-\mathrm{TC}$

Where,

$\Pi=$ Net return $(\mathrm{Tk} / \mathrm{ha}) ; \mathrm{TR}=$ Total return (Tk/ha); TC $=$ Total costs (Tk/ha)

Thus, the model can be written as:

$\Pi=\sum \mathrm{Q}_{\mathrm{y}} \cdot \mathrm{P}_{\mathrm{y}}+\sum \mathrm{Q}_{\mathrm{b}} \cdot \mathrm{P}_{\mathrm{b}}-\sum_{\mathrm{i}=1}^{\mathrm{n}}\left(\mathrm{X}_{\mathrm{i}} \cdot \mathrm{P}_{\mathrm{xi}}\right)-\mathrm{TFC}$ 
Where, $Q_{y}=$ Total quantity of (paddy) output $(\mathrm{kg} / \mathrm{ha}) ; P_{y}=$ Per unit price of (paddy) output (Tk/kg); $Q_{b}=$ Total quantity of the concerned byproduct $(\mathrm{kg} / \mathrm{ha}) ; P_{b}=$ Per unit price of the relevant byproduct $(\mathrm{Tk} / \mathrm{kg})$; $X_{i}=$ Quantity of the concerned $\mathrm{i}^{\text {th }}$ input; $P_{x i}=$ Per unit price of the relevant $\mathrm{i}^{\text {th }}$ input; TFC $=$ Total fixed cost involved in production process; and $i=1,2,3, \ldots, n$ (number of inputs).

Strength, Weakness, Opportunity, and Threat (SWOT) analysis has been done at the end to identify the major drivers of BKB's agricultural credit programme.

\section{RESULTS AND DISCUSSION}

\section{Cost of credit}

Figure 1 presents the item-wise average cost of receiving hundred taka loans from BKB in the study area. On average the cost of receiving a hundred Taka loan from BKB was Tk 10.23. Among the major cost items, the official cost was significantly lower (e.g., application fee, Tk 0.89) than unofficial costs (Tk 9.34). The entertainment cost (Tk 6.82) was the highest among all unofficial costs followed by transportation and food cost (Tk 1.63) and the opportunity cost of man-days for time pass to approve the credit (Tk 0.89). It is to be mentioned that the item-wise cost of receiving a loan was estimated from the response of the borrowers and simplified accordingly by converting the loan amount to a hundred taka. That findings obviously not delineate that the afore-mentioned costs or their share will be the same for next each hundred taka loan or the total loan as a whole. It is being reported by the borrower respondents that the actual total cost ranges between Tk 800- 5200 based on the total amount of loaned money in the study area. Farmers mentioned that fulfilling an undue demand of brokers (dalal) and/or some unscrupulous bank officials covers a significant portion of the cost, which appears as a huge drawback in the case of obtaining a loan from BKB. Also, farmers had to visit the respective branch of the bank several times for getting their loan which made them incur a mentionable amount of cost for transportation, food as well as the opportunity cost of mandays for time passes to approve the loan. It is to be mentioned that, Miah et al. (2006) also listed the above-mentioned items of costs for obtaining agricultural credit from Grameen Bank (GB) as well as RAKUB.

\section{Loan utilization pattern}

Ensuring proper utilization of agricultural credit for crop production is critically important to achieving the bank's goal of disbursing loans to farmers. Figure 2 exemplifies the utilization pattern of obtained loans on MV Boro cultivation in the study areas. It depicts that farmers used more than half $(54 \%)$ of the BKB sanctioned loan for Boro rice cultivation, about $21 \%$ to purchase foods for family consumption or other family expenditures and the rest $(25 \%)$ was used for other purposes such as reimbursement of the previous loan from formal and informal sources, wedding and various other incomegenerating activities including petty trading. Paying wage to the labourer was the major cost item of rice production for which borrower farmers had to pay $15 \%$ of their obtained loan as Boro cultivation is a labourintensive endeavour. Again, as most of the sample farmers were small and marginal, land mortgaged constituted a significant amount as an item of rice production cost in the study villages. On the other hand, farmers in the study areas spent one-fourth of their obtained loans in different non-farm activities like repayment of the old loan, investment in trade, petty business, bribe and so on. Previous studies (Miah et al., 2006; Deb et al., 2020) also exposed a similar kind of utilization pattern of the borrower farmers from RAKUB and GB. 


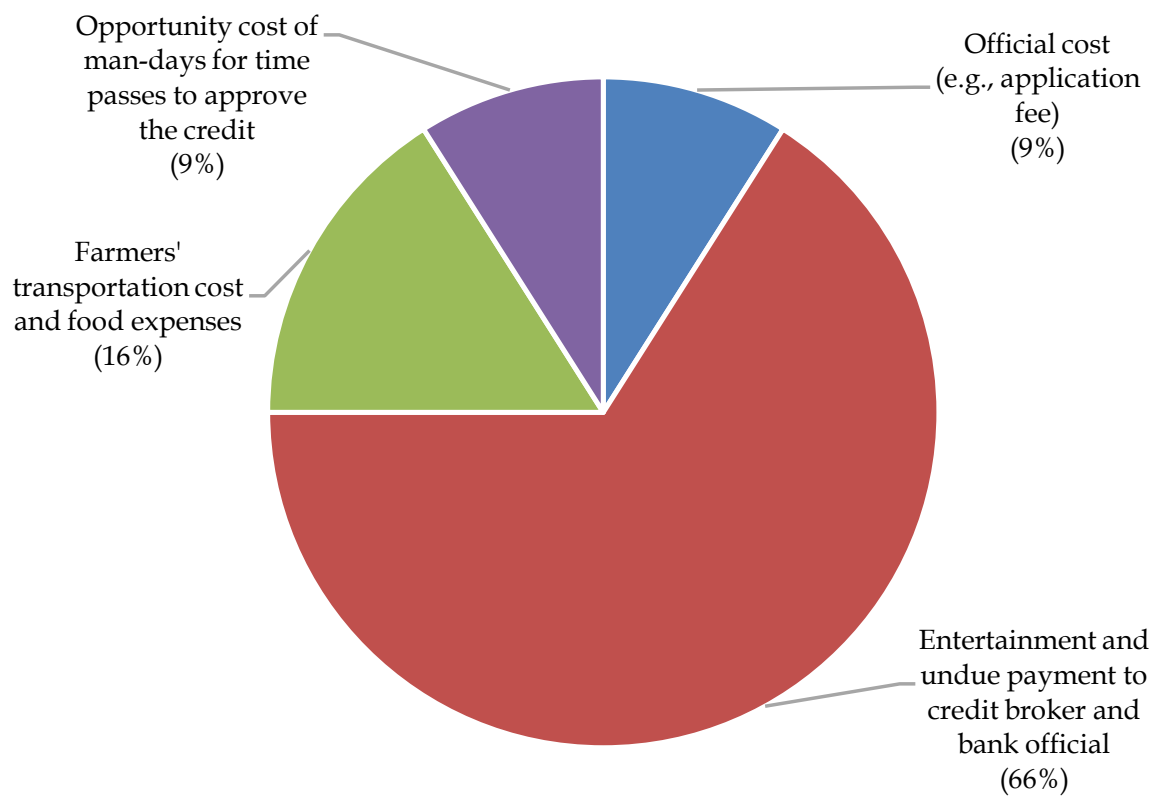

Fig. 1. Item-wise farmers' cost of receiving a hundred taka loan from BKB.

Source: Prepared by authors based on field survey.

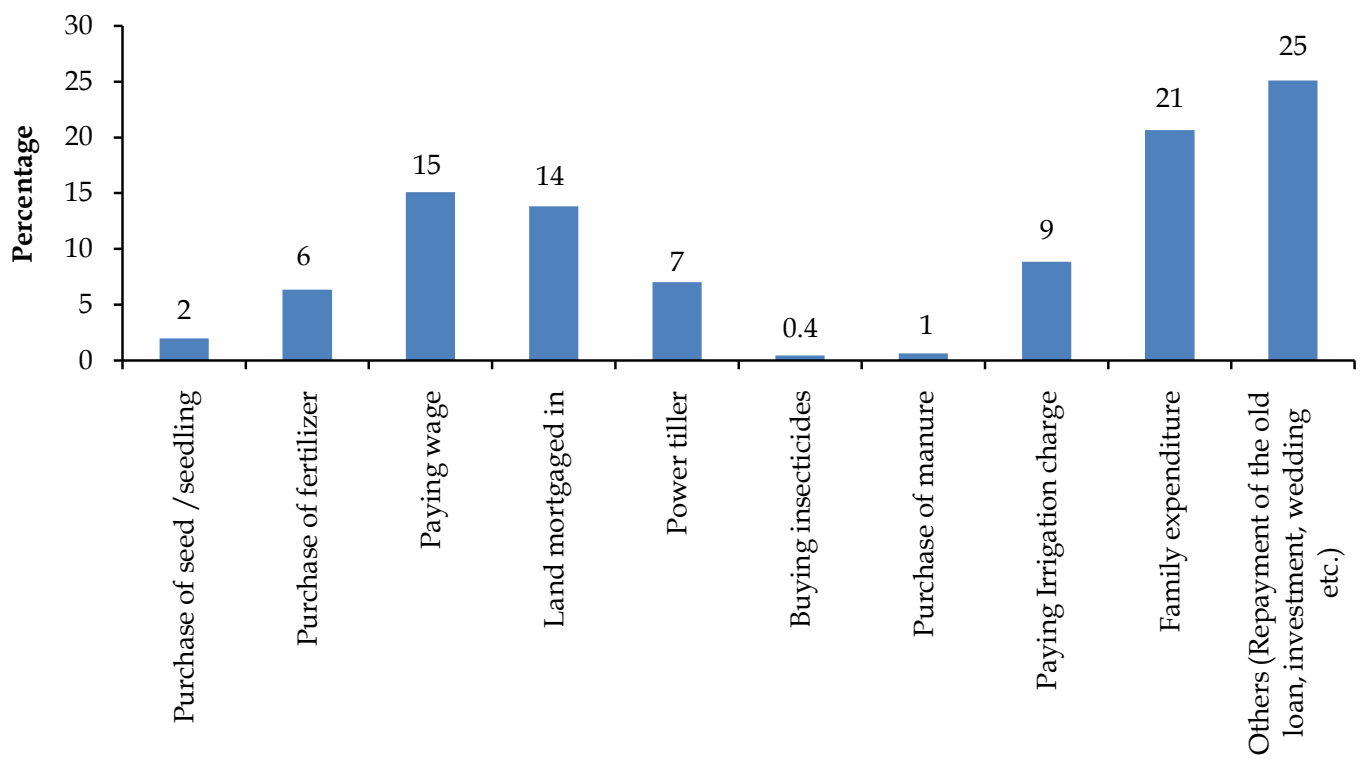

Activities

Fig. 2. Loan utilization patterns of Boro rice farmers. Other activities include repayment of the old loan, investment, wedding, etc.

Source: Prepared by authors based on field survey. 


\section{Input use pattern in the study areas}

Table 2 shows the per hectare input use pattern of credit users and non-users for Boro rice cultivation. Major operations of Boro rice cultivation such as harvesting, carrying, and threshing were carried out by hired labour but other activities were mainly performed by family labour in the study village. It revealed that credit users and non-users applied approximately equal amounts of fertilizer even though it was argued in the study before that the credit non-user have less access to some inputs. However, in case of fertilizer application, farmers in Bangladesh usually apply more fertilizer than the recommended dose irrespective of their class or status (BRRI, 2018). High government subsidy that let the fertilizer price be minimum as well as lack of proper knowledge about optimum practice might be a probable explanation of this fact. On the contrary, per hectare labour deployment for credit users was higher than the farmers who did not use loaned money. It may be because credit users had a higher ability to hire labour and other inputs than credit non-users. These findings also support the previous finding that higher credit use is allied with the improved use of inputs in the production process (Satyasai, 2012).

\section{Costs of cultivation}

Table 3 presents the per hectare cost of credit users and credit non-users for Boro rice cultivation in the study villages. It was found that per hectare variable cost of credit users (Tk $88,123 /$ ha) was higher than credit nonusers (Tk 84,234/ha) in the study area. It was mainly due to the per hectare labour cost of credit users (Tk 47,220/ha) was higher than the credit non-users (Tk 43,140/ha).

It is to be mentioned that apart from the higher amount of hired labour used by the credit users, there are some differences in land preparation as well as irrigation cost though those are not significant. This extra cost of credit users mainly occurred for using the irrigation schemes more intensively as well as more hired labour than credit non-user.

Table 2. Per hectare input use pattern of credit user and non-user for Boro rice cultivation in the study villages.

\begin{tabular}{ccc}
\hline Input item & Credit user & Credit non-user \\
\hline Human labour (man-day/ha): & 90 & 80 \\
Hired & 52 & 40 \\
Family & 38 & 40 \\
Seed (kg/ha) & 41 & 41 \\
Fertilizer (kg/ha): & & 259 \\
Urea & 252 & 101 \\
TSP & 99 & 78 \\
MP & 80 & 10 \\
DAP & 10 &
\end{tabular}

Source: Prepared by authors based on field survey. 
Table 3. Per hectare cost of credit user and credit non-user for Boro rice cultivation in the study villages.

\begin{tabular}{lcc}
\hline Cost item & Credit user & Credit non-user \\
\hline Seedbed preparation (Tk/ha) & 2,490 & 2,487 \\
Seed (Tk/ha) & 1,740 & 1,742 \\
Human labour & $47,220(44.23)$ & $43,540(42.23)$ \\
$\quad$ Family labour & 10,760 & 12,580 \\
$\quad$ Hired labour & 16,240 & 11,960 \\
$\quad$ Contract & 20,220 & 19,100 \\
Land preparation cost (Tk/ha) & $8,115(7.60)$ & $8,095(7.85)$ \\
Fertilizer (Tk/ha) & $9,110(8.53)$ & $9,455(9.17)$ \\
$\quad$ Urea & 3,820 & 4,322 \\
$\quad$ TSP & 2,167 & 2,222 \\
$\quad$ MP & 1,155 & 1,170 \\
$\quad$ DAP & 255 & 260 \\
Cowdung (Tk/ha) & 1,713 & 1,481 \\
Irrigation (Tk/ha) & $15,200(14.24)$ & $14,689(14.23)$ \\
Herbicide (Tk/ha) & 380 & 308 \\
Insecticide (Tk/ha) & 2,068 & 2,198 \\
Interest on operating capital @10 for five months & 1,800 & 1,720 \\
Variable cost (Tk/ha) & $88,123(80.86)$ & $84,234(80.02)$ \\
Land rent (Tk/ha) & $18,515(17.34)$ & $18,595(18.32)$ \\
Total cost (Tk/ha) & $1,06,638$ & $1,02,829$ \\
\hline Source Propar & &
\end{tabular}

Source: Prepared by authors based on field survey.

\section{Profitability}

Table 4 shows per hectare returns of credit users and non-user for Boro rice cultivation. Per hectare yield of credit users (5.89 ton/ha) was slightly higher than that of credit nonusers (5.59 ton/ha) due to better crop management (timely planting, weeding, and application of fertilizer by credit user because of availability of capital to purchase inputs timely as mentioned by the respondents). It is also evident from the past study (Datta and Ghosh, 2013) that borrowers of the formal sector have better access to electricity and irrigation facilities, belong to the comparatively privileged group of the society, and have better access to infrastructure facilities. For the same reason, per hectare gross return of credit users (Tk 10,6815/ha) was higher than that of the credit non-users (Tk 96,984/ha) as credit users harvested higher yields and higher price of paddy/rice for not selling the marketable surplus immediately after harvesting. Similarly, the ratio of benefit over cost (BCR) indicated that BKB credit borrowers were more benefited through Boro rice cultivation than non-borrowers. Even though the farm productivity, income level as well as agriculture development are closely related to agricultural credit (Sharma and Prasad, 1971) but it is always difficult to determine a causal relationship between agriculture credit and production due to the presence of serious endogeneity problem (Das et al., 2009). However, improved supply and well-administered valuing of credit assist to intensify the agricultural productivity and the well-being of cultivators as well as all actors involved in the agricultural sector as credit is considered as life-line of the total investments made in agriculture (Sriram, 2007). 
Table 4. Per hectare returns of credit user and non-user for Boro rice cultivation.

\begin{tabular}{lcc}
\hline \multicolumn{1}{c}{ Item } & Credit user & Credit non-user \\
\hline Yield (kg/ha) & 5,880 & 5,585 \\
Paddy price (Tk/kg) & 15.96 & 15.05 \\
Return from paddy (Tk/ha) & 93,845 & 84,054 \\
Return from Straw (Tk/ha) & 12,970 & 12,930 \\
Gross return (Tk/ha) & $1,06,815$ & 96,984 \\
Variable cost (Tk/ha) & 88,123 & 84,234 \\
Total cost (Tk/ha) & $1,06,638$ & $1,02,829$ \\
Gross margin (Tk/ha) & 19,401 & 14,470 \\
Net return (Tk/ha) & 966 & $-6,124$ \\
Unit cost of production (Tk/kg) & 18.33 & 17.36 \\
BCR on cash cost basis & 1.21 & 1.15 \\
BCR on full cost basis & 1.01 & 0.94 \\
\hline
\end{tabular}

Source: Prepared by authors based on field survey.

Drivers of BKB's agricultural credit 2020). As a part of internal control, integrated programme

compliance system as well as smooth operation, BKB has also established 63 fieldlevel audit offices of which nine at divisional and 54 at regional levels (BKB, 2020).

Table 5 delineates the results obtained from the SWOT analysis of the BKB agricultural credit programme in the study area. SWOT of $B K B^{\prime}$ s agricultural credit programme in the study area was identified based on the respondents' opinion and secondary sources, which help to determine the drivers of the agricultural credit programme of BKB.

\section{Strengths}

Wide operational network. It has been considered as one of the strengths of the BKB agricultural credit programme. It has a total of 1,038 branches all over the country covering 50 districts, nine city corporations, and 607 unions (BKB, 2020).

Well-established infrastructure. Since the establishment, BKB is trying to reach the rural community of the country. Being one of the largest specialized banks in the country currently, BKB is operating its banking activities through seven corporate, 239 cities, and 792 rural branches in the country (BKB,

Experienced human resource. $B K B$ is running with 9,430 manpower against the approved number of 13680 as of 31 December 2010 (BKB, 2020). Even though BKB is running with inadequate manpower in some cases but as one of the oldest specialized banks, it is holding very experienced human resources in the banking sector of the country.

Lower interest rate. One of the key mandates of $B K B$ is to help in poverty alleviation in the rural community. Thus, BKB is extending an agricultural loan with comparatively lower interest as mentioned by the respondents.

\section{Weaknesses}

Long and complex institutional procedure. The key hitches faced by farmers in securing agricultural credit from the formal sector banks are the long and complex institutional procedure. BKB is not an exception in that case 
as well. Respondents irrespective of their categories pointed to this as the main difficulties in securing agricultural credit from $\mathrm{BKB}$ in the study area.

Lack of timely loan assistance. The respondents identified lengthy and delayed loan approval processes as major flaws in BKB's agricultural credit program. The same scenario was observed in another study (Deb et al., 2020), in which 63 percent of RAKUB agricultural loan recipients claimed that they did not receive credit on time.

Strong need for collateral. The strong need for collateral in institutional sources like BKB in turn enforces plenty of formalities on credit seekers that make them finally penchant for taking a loan from semi-institutional and noninstitutional sources. Majority of RAKUB borrower farmers in Chapai Nawabganj district mentioned the strong need for collateral in institutional sources as a major hindrance for poor and marginal farmers (Deb et al., 2020).

Poor institutional capacity. Even though $\mathrm{BKB}$ has many branches in the rural areas but these are still inadequate against the requirement. Moreover, there are shortages of manpower, which often make the bank to limit its operations as reported by the respondents.

\section{Opportunities}

As a key specialized bank, BKB is always having the privilege of being patronized by the government. With the increasing capital, BKB is characterized by plenty of programmes targeting the rural community which will be extended further by the government policy and interventions. Due to its diversified programmes, government patronization, lower interest rate, and fastest-growing demand for agricultural credit, BKB has wide social acceptance among the rural community. It has been the most reliable formal source of agricultural credit in the study area.

\section{Threats}

The prevalence of brokers or unscrupulous bank officials results in higher non-interest costs in loan transactions for the borrowers. The higher non-interest cost of BKB credit for the small farmers acts as a hindrance to the development of their productive forces. Moreover, institutional credit is supposed to be allocated according to the relative efficiency of the cultivator rather than being allocated according to the economic and political supremacy of credit recipients. Agricultural loans are often used for political motives. To avoid these kinds of hassles farmers especially small and marginal farmers often go to NGOs for borrowing money despite higher interest rate.

Table 5. SWOT analysis to BKB agricultural credit programme in the study areas.

\begin{tabular}{ll}
\hline \multicolumn{1}{c}{ Strength } & \multicolumn{1}{c}{ Weakness } \\
\hline Wide operational network & Long and complex institutional procedure \\
Well established infrastructure & Lack of timely loan assistance \\
Experienced human resource & Strong need for collateral \\
Lower interest rate & Poor institutional capacity \\
\hline \multicolumn{1}{c}{ Opportunity } & Threat \\
\hline Government patronization & Prevalence of brokers or unscrupulous bank officials \\
High social acceptance & Competition with NGOs \\
Growing demand for agricultural credit & Political influence \\
\hline
\end{tabular}




\section{CONCLUSION}

Agricultural credit has gained importance among policymakers, bankers, and agricultural fraternities in Bangladesh. As a result, the extent of this programme is increasing every year in terms of both target and actual disbursement. Farmer's loan sanction cost substantially high due mainly to undue deals with some unscrupulous bank officials and brokers. The borrower used nearly half $(54 \%)$ of the BKB sanctioned credit for Boro rice cultivation, about $21 \%$ to purchase foods for family consumption, and the rest (25\%) for other purposes (e.g., reimbursement of previously received credit of formal and informal sources, and various other income-generating activities including petty trading). The cost of Boro rice cultivation was higher for credit users as they used more labour, and they obtained higher returns as credit users harvested higher yield. It may due to better management (e.g., timely performed intercultural operations because of availability of capital) and for not selling the marketable surplus immediately after harvesting. The benefit-cost ratio (BCR) indicated that $\mathrm{BKB}$ credit borrowers obtained more benefits through Boro rice cultivation than nonborrowers. Wide operational network with well-established infrastructure and experienced manpower, the lowest interest rate was being reported as strengths of the BKB agricultural credit programme whereas long and delayed institutional procedure, the strong need for collateral, and poor institutional capacity was being identified as the weaknesses of the programme. On the other hand, government patronization, high social acceptance, and the fastest-growing demand for agricultural credit were being mentioned as great opportunities while the prevalence of brokers or corrupt officials and political influence were marked as major threats to the agricultural credit programme of BKB. Making the whole agricultural credit programme procedure more convenient and user-friendly for the borrower farmers may reduce the amount of unofficial cost of loan sanctioning, which will affect the ultimate goal of the programme to a positive extent. The presence of brokers or notorious activities by the corrupt bank officials should be stopped by any means. The requirements for collaterals should be reconsidered in order to ensure the inclusion of poor and marginal group of farmers. Also, the allocation of credit should be increased to enable the farmer to cope up with modern input-intensive Boro cultivation. $\mathrm{BKB}$ needs to be strengthened more by including more trained personnel and increasing the institutional capacity with adequate facilities. However, focusing on such an important tool for the country's long-term crop production, more advanced research is strongly recommended.

\section{AUTHORS' CONTRIBUTION}

LD and MARS generated idea; MABS coordinated the research; LD developed methodology; LD, MARS and MABS provided scientific insights; LD and MARS gathered data; LD carried out analysis, synthesis and drafted the manuscript; LD, MARS and RB did the writings of all versions of the manuscript; MARS, MABS and RB performed critical review and editing; All authors read and approved the final manuscript.

\section{ACKNOWLEDGEMENT}

The authors would like to acknowledge Bangladesh Krishi Bank (BKB) Fulbaria branch for their support during data collection. Authors would also like to acknowledge Bangladesh Rice Research Institute for their support during the research.

\section{DECLARATION OF INTERESTS}

The authors declare that they have no known competing financial interests or personal relationships that could have appeared to influence the work reported in this paper. 


\section{REFERENCE}

Alauddin, M and J Biswas. 2014a. Agricultural Credit in Bangladesh: Present Trend, Problems and Recommendations. Journal of Economics and Sustainable Development, 5(37): 11-22.

Alauddin, M and J Biswas. 2014b. Agricultural Credit in Bangladesh: Trends, Patterns, Problems and Growth Impacts. The Jahangirnagar Economic Review, 25(14): 125-138.

BB (Bangladesh Bank). 2018. Annual Report (July 2017June 2018), 17: 90-91 Bangladesh Bank. BinswangerMkhize, H P. 2012. Is there too much hype about index-based agricultural insurance? Journal of Development studies, 48(2): 187-200.

BKB (Bangladesh Krishi Bank). 2020. Bangladesh Krishi Bank. Retrieved from URL http://www.krishibank.org.bd (Online, last accessed January, 2020).

BRRI (Bangladesh Rice Research Institute). 2018. Estimation of cost and return of MV rice cultivation at farm level. BRRI Annual report 2017-2018, Bangladesh Rice Research Institute, Gazipur 1701, Bangladesh, 167-69.

Das, A, M Senapati and J John. 2009. Impact of agricultural credit on agriculture production: an empirical analysis in India. Reserve Bank of India Occasional Papers, 30: 75-107.

Datta, S and A Ghosh. 2013. Explaining access to credit by rural households: results based on a study of several states in India. Working Paper, Indian Institute of Management, Ahmedabad, India.

Deb, L, M A R Sarkar, M S Rahaman, M Asaduzzaman and M A B Siddique. 2020. Agricultural Credit and Profitability of MV Boro Rice Cultivation at Farm Level in Some Selected Areas of Chapai Nawabganj District. Journal of Bangladesh Agricultural University, 18(3): 667-673. DOI: 10.5455/JBAU.99065

Deb, L, M R Mian, M Asaduzzaman, S S Mitul and M S Rahaman. 2016. Socioeconomic Analysis of Different Categories of Farm in Selected Areas of Mymensingh, Bangladesh. International Journal of Agricultural Science, Research and Technology in Extension and Education Systems, 6(1): 29-36.

Deb, U. 2016. Agricultural transformation in Bangladesh: extent, drivers and implications. Conference: $15^{\text {th }}$ National Conference of the Bangladesh Agricultural Economists Association (BAEA) on "Transformation of Agricultural Sector in Bangladesh: 21 ${ }^{\text {st }}$ Century" held on 22-23 January 2016 at the Bangladesh Agricultural Research Council (BARC) Auditorium, Dhaka, Bangladesh.

Hossain, M. 1988. Credit for alleviation of rural poverty: The Grameen Bank in Bangladesh. Research reports 65, International Food Policy Research Institute (IFPRI), 9-85.

Jabber, M A, M A S Mondal and K K Elahi. 1981. Usufructuary land mortgage: A process contributing to growing landless in Bangladesh. J Agril Econ, 8(2): 37-52.

Khan, W, S Fatima and M Jamshed. 2017. Agricultural Credit-led Agricultural Growth: A VECM Approach. Asian Journal of Agricultural Extension, Economics \& Sociology, 19(1): 1-16.

Miah, M K, A A Alam and A H M A Rahman. 2006. Impact of agricultural credit on MV Boro Rice cultivation in Bangladesh. Journal of Agriculture $\mathcal{E}$ Rural Development, 4(1): 161-168. DOI: 10.3329/jard.v4i1.784.

Rahman, S M and S Al-Amin. 2016. Measuring the Differences in Cost of Production: A Study on Boro Rice Farming in Bangladesh. Journal of Business Studies, 37(1).

Salam, M U, B K Mahalder, H Bhandari, M S Kabir, M A R Sarkar, B Nessa and M A Ali. 2019. Policy Directions Toward Increasing Rice Productivity - Lessons from Bangladesh. In: Advances in Rice Research for Abiotic Stress Tolerance, M Hasanuzzaman, M Fujita, K Nahar and J K Biswas (Eds.). Woodhead Publishing, 895-913.

Satyasai, K J S. 2012. Access to rural credit and input use: An empirical study. Agricultural Economics Research Review, 25: 461-471.

Sharma, J B and B Prasad. 1971. An assessment of production credit needs in developing agriculture economies. Indian Society of Agricultural Economics, 26(4): 503- 511.

Spio, K. 2006. The impact and accessibility of agricultural credit: A case study of small-scale farmers in the Northern Province of South Africa. PhD dissertation, University of Pretoria, Lynnwood Rd, Hatfield, Pretoria, 0002, South Africa.

Sriram, M S. 2007. Productivity of Rural Credit: A Review of Issues and Some Recent Literature. Indian Institute of Management, Ahmedabad, Working Paper No. 2007-06-01. 